University of Wollongong

Research Online

Faculty of Social Sciences - Papers (Archive) Faculty of Arts, Social Sciences \& Humanities

$1-1-2017$

Beyond the academic precariat: a collective biography of poetic subjectivities in the neoliberal university

\author{
Catherine Hartung \\ University of Otago, cjh966@uow.edu.au \\ Nicoli Barnes \\ Charles Darwin University \\ Rosie Kate Welch \\ Monash University, rwelch@uow.edu.au \\ Gabrielle H. O'Flynn \\ University of Wollongong, gabriell@uow.edu.au \\ Jonnell Uptin \\ University Of Sydney, jeu539@uowmail.edu.au
}

See next page for additional authors

Follow this and additional works at: https://ro.uow.edu.au/sspapers

Part of the Education Commons, and the Social and Behavioral Sciences Commons

Research Online is the open access institutional repository for the University of Wollongong. For further information contact the UOW Library: research-pubs@uow.edu.au 


\title{
Beyond the academic precariat: a collective biography of poetic subjectivities in the neoliberal university
}

\author{
Abstract \\ The 'neoliberal turn' in the higher education sector has received significant intellectual scrutiny in recent \\ times. This scrutiny, led by many established academics working within the sector, has highlighted the \\ negative repercussions for teaching and research staff, often referred to as the 'academic precariat' due \\ to their tenuous employment prospects within an increasingly market-driven system. This critique of the \\ modern university can also inadvertently position academics as either resisting or complying with \\ neoliberal governance. This does not adequately account for the nuanced and poetic ways in which \\ professional, personal and gendered subjectivities are formulated, intertwined and negotiated. In this \\ paper we draw on the six overlapping yet distinct narratives of the six female authors, all early-career \\ academics from Australia. We capture and analyse these narratives through collective biography, a \\ qualitative methodology underpinned by the work of Davies and Gannon and others, that helps us to move \\ beyond the 'good vs. bad', 'resistance vs. compliance' debates about academic life. We identify aspects of \\ our lived subjectivities that offer rupture through poetic and hopeful ways of understanding how \\ academics construct and negotiate their lives.
}

\section{Keywords}

academic, precariat:, collective, beyond, biography, subjectivities, university, neoliberal, poetic

\section{Disciplines}

Education | Social and Behavioral Sciences

\section{Publication Details}

Hartung, C., Barnes, N., Welch, R., O'Flynn, G., Uptin, J. \& McMahon, S. (2017). Beyond the academic precariat: a collective biography of poetic subjectivities in the neoliberal university. Sport, Education and Society, 22 (1), 40-57.

\section{Authors}

Catherine Hartung, Nicoli Barnes, Rosie Kate Welch, Gabrielle H. O'Flynn, Jonnell Uptin, and Samantha McMahon 


\section{Beyond the academic precariat: a collective biography of poetic subjectivities in the neoliberal university}

Catherine Hartung ${ }^{1 \mathrm{a}}$, Nicoli Barnes ${ }^{\mathrm{b}}$, Rosie Welch ${ }^{\mathrm{c}}$, Gabrielle O'Flynn ${ }^{\mathrm{d}}$, Jonnell Uptin $^{\mathrm{e}}$ and Samantha McMahon ${ }^{\mathrm{d}}$

${ }^{\mathrm{a}}$ College of Education, University of Otago, Dunedin, New Zealand; ${ }^{\mathrm{b}}$ School of Education, Charles Darwin University, Darwin, Australia; ' $S c h o o l$ of Education, Monash University, Melbourne, Australia; ${ }^{\mathrm{d}}$ School of Education, University of Wollongong, Wollongong, Australia; ${ }^{\mathrm{e}}$ Faculty of Education and Social Work, University of Sydney, Sydney, Australia

1 corresponding author: catherinehartung@gmail.com 


\begin{abstract}
The 'neoliberal turn' in the higher education sector has received significant intellectual scrutiny in recent times. This scrutiny, led by many established academics working within the sector, has highlighted the negative repercussions for teaching and research staff, often referred to as the 'academic precariat' due to their tenuous employment prospects within an increasingly market-driven system. This critique of the modern university can also inadvertently position academics as either resisting or complying with neoliberal governance. This does not adequately account for the nuanced and poetic ways in which professional, personal and gendered subjectivities are formulated, intertwined and negotiated. In this paper we draw on the six overlapping yet distinct narratives of the six female authors, all early career academics from Australia. We capture and analyse these narratives through collective biography, a qualitative methodology underpinned by the work of Davies and Gannon and others, that helps us to move beyond the 'good vs bad', 'resistance vs compliance' debates about academic life. We identify aspects of our lived subjectivities that offer rupture through poetic and hopeful ways of understanding how academics construct and negotiate their lives.
\end{abstract}

Keywords: higher education, neoliberalism, collective biography, subjectivity, early career academics

\title{
Introduction
}

The rise of the 'neoliberal university', understood as a market-driven system emphasising performance measurement and individual accountability, has been the subject of much public debate in recent times. Of particular concern in these debates is the impact of the neoliberal turn on academic staff, particularly female academics and those early in their careers who are attempting to 'carve out a niche' in an increasingly competitive and uncertain profession. In responding to this predicament, the literature tends to focus on the institutional relations of power that restrict or dictate what is possible in the 'academic precariat' (Nöbauer, 2012). In such analyses of the institutional mechanisms governing academic life there can be little room for a more nuanced or hopeful reading of the diverse ways in which those in the academic precariat come to understand themselves and negotiate their lives as academic subjects. As Ziarek (2001, p. 3) notes, such an approach can shift "the emphasis from the subjective to the disciplinary, institutional mechanisms of control and thus fails to interpret the embodiment as a possible locus of revolt or ethical responsibility".

In shifting the focus back onto the embodied subject and the possibilities for a more productive and hopeful academic future, this paper draws on six diverse poetic vignettes of life 'post-PhD', based on the experiences of the papers' authors, all of whom completed their doctoral candidature at the University of Wollongong between 2004 and 2014 under the supervision and theoretical influence of established 
academics in the interdisciplinary areas of young people's health and physical education and educational sociology, Jan Wright and/or Valerie Harwood. Notably to the PESP field and this special issue, the former of these supervisors has contributed a significant body of scholarship to the PESP field both nationally and internationally. By writing ourselves into the research, we acknowledge the contribution of our supervisors and their colleagues in terms of navigating professional identities within and beyond the academy within and without the PESP field.

As Australian women who have undertaken doctoral studies at the same university in the same education faculty with the same supervisors around the same time period, there are significant and obvious overlaps in our experiences. One such overlap was a feeling of 'burnout' at the end of the dissertation, described by Maslach and Goldberg (cited in Stubb, Pyhältö \& Lonka, 2011, p. 34) as a combination of overwork and "emotional exhaustion, cynicism and reduced sense of efficacy". Yet, there remain many important differences in the experiences and subjectivities we brought to the doctoral 'journey' and the lives and subjectivities we have negotiated during and after candidature; differences we believe are worthy of further exploration. While we have all engaged with issues related to the education and governance of young people in our research, two of the authors in particular are Physical Education and Sport Pedagogy (PESP) early-career academics who position themselves within and without the field, drawing on health education and social theory to mobilise academic research within the field. Such a position offers us a unique ability to contribute to this special issue, one which recognises that up until now, limited research has considered the experiences of early career academics within PESP (Casey \& Fletcher, 2012).

Indeed, the idea for this paper came after an informal catch up following the graduation ceremony of two of the authors, when we shared our experiences of life post-PhD over lunch. It was clear that we all had quite different experiences of life post-PhD and that there were many aspects to our experience that did not seem to be reflected in the literature on early career academics and higher education. This moment of memory sharing was recorded by one of the authors who had graduated 12 months prior. There was a mind-bodily sense that something was taking place in the memory sharing. A common discursive thread was connecting our experience; that each of us learnt to carefully apply poststructuralism in our research work, to draw attention to the contexts of knowledge production in educational projects. By way of 
the doctoral process, our perspective was fine-tuned to notice contemplative moments or the 'spaces-in-between' (Somerville, 2005) and disrupt thinking as usual. Indeed, it was this type of thinking that gave rise to this paper.

Yet such a poststructural approach rooted in Foucauldian discourse analysis can negate the possibility of acknowledging the "veil of silence around emotions and bodies" (Davies \& Gannon, 2006b, p. 3). Our different memories in the sharing of stories could be read as 'unreliable' and thus there is a materiality to our lived experiences. Different biases were assembled in each of our memories of being and becoming a PhD graduate; a smattering of ordinary events that have short-term effects and those that had sensual resonance. The reunion lunch was unwittingly therapeutic yet this was not surprising given the shared discursive meaning making through which we have become academic subjects. Our diverse memories were a collection of “mo(ve)ments" (Davies \& Gannon, 2006b, p. 7).

The proximity of our commitment to writing up our lived memories after the lunch was a deliberate process for analysing moments that were otherwise forgotten or discarded as professionally insignificant. This writing process was especially important as women academics where historically gender has always been related to discursive formations of authorship and writing has always been tied to certain kinds of masculinity (see, for example, Gonick, 2014; Ahmed, 1998; Gilbert, 1992). In writing our narratives as six female early career academics, one memory became threaded to the past, and then to the current circumstances; reflections on being and becoming, emotions, questioning what happened, the feel, look and embodied details. The memories were then analysed in 'collective biography', a method that draws on memory stories to investigate processes of subjectification (Gonick, 2014). Our memories were treated as discursive/textual sites for "tracing such inscriptions as they manifest on and in bodies" (Davies \& Gannon, 2006b, p. 13). The next stage was to analyse and unravel the 'discursive nets' with care and to construct a "“we' who speaks" in order to analyse "bodies and theory as integral to one another" (Davies \& Gannon, 2006b, p. 14). In this way our "theoretical selves" were not neatly divorced from our "embodied story-telling selves" (Gale \& Wyatt, 2008, p. 250). This treatment and interpretation of our experiences troubles the discursive nature of the neoliberal and academic precariat, opening up 'lines of flight' (Deleuze \& Guattari, 1988) for the nuances of what our minds-bodies made and continue to make possible. 
Neoliberalism is not a theory of everything (or everyone)

Rowlands and Rawolle (2013, p. 269) challenge the popular yet vague critique of neoliberalism in education research, arguing that "by using 'neoliberalism' in a nonspecific way (and by not challenging the myths associated with its use) we are at risk of perpetuating the dominant discourse of neoliberalism rather than disrupting or challenging it." Similarly, while recognising the importance and necessity of previous critiques of the neoliberal university, we are interested in going beyond typical arguments and complaints that can arise from these critiques without downplaying the difficulties these discussions present. We want this work to 'sit alongside' these discussions not just as a contrast or a counter to what already exists, but also as a representation of the complex academic experience.

\section{Critiques of the neoliberal university, the academic precariat and a radical politics of hope}

Critical accounts of the neoliberal university are commonplace in current discussions on higher education. Many offer broad sociological and poststructural critiques of institutional decisions that are creating ever-increasingly precarious employment prospects for those within the academy (e.g. Peters, 2000, 2013; Olssen \& Peters, 2005; Connell, 2013; Peters, Marshall \& Fitzsimons, 2000; Rizvi \& Lingard, 2010; Giroux, 2011, 2014). Some critiques present a 'call to arms', encouraging academics to actively resist the processes of neoliberalism within their institution. For example, Giroux (2014, p. 38), who critiques the neoliberal university as "a market-driven paradigm that seeks to eliminate tenure, turn the humanities into a job preparation service, and transform most faculty into an army of temporary subaltern labor" argues that "resistance is no longer an option, it is a necessity" (Giroux, 2014, p. 57).

Underlying this critique is a particular understanding of 'precarity', which, according to Giroux (2014, p. 55), "has become a weapon to both exploit adjuncts, part-time workers, and temporary laborers and to suppress dissent by keeping them in a state of fear over losing their jobs." The notion of a 'precariat' has been popularised by the recent work of Standing (2011, p. 16), who defines it as a new class of worker whose work is dictated by increased labour market flexibility and insecurity and leads to "a precariat existence, of living in the present, without a secure identity or sense of development achieved through work or lifestyle". Standing argues this precariousness 
is politically, socially and economically 'dangerous', resulting in anger, anomie, anxiety and alienation. In this regard, those precariously positioned within the academy are being labelled part of an 'academic precariat' (see, for example, Nöbauer, 2012; Fischer, 2013; Ginn, 2014). While there is little research of academic precarity specific to PESP, the discipline is certainly not immune to entrenched workplace relations of casualisation across the sector (May, Strachan, Broadbent \& Peetz, 2011).

This tendency to reduce the experiences of academia to the neoliberal and institutional may dominate scholarly sociological debate in relation to modern academia and academics but it is not the only narrative within the literature. For example, Barcan (1996, p. 128) has emphasised the need to move beyond the caricature of the academic as a "disembodied rationality - an egg-head in an ivory tower" to focus instead on the "possible bodily effects of such constructions". In more recent work drawing on the international media, political discourses and her own professional experience, Barcan (2013) has examined the possibilities and politics of 'hope' in the neoliberal university with an emphasis on collegiality, intellectual honesty and courage. Similarly, Ng (2015, p. 171) in his paper exploring the possibilities of 'faith' in counteracting the competitive individualism and managerialism of the neoliberal university, argues that "paying collective attention to the faithful pulsating heart of academia might foster sympathetic relations of reciprocity and solidarity amongst para-academics ${ }^{2}$ and between para-academics and tenured academics".

Kenway, Boden and Fahey $(2014$, p. 2) reflecting upon their own experiences as academics and their feelings of a lost agency, have identified the need to find “resources of hope". Drawing on Williams' earlier work (1989, p. 118), which argues that "to be truly radical is to make hope possible rather than despair convincing", Kenway and colleagues (2014, p. 2) emphasise the need to "critically, imaginatively, positively and optimistically" work to move beyond the 'doom and gloom' of the popular critiques of the neoliberal university. Describing their collective discussions and experiences at a recent conference, they write:

\footnotetext{
${ }^{2}$ The term 'para-academic' refers to "a person but, also, potential collectivities of people and practices existing simultaneously inside, outside, and alongside the conventional academy" (Withers \& Wardrop, 2014, p. 8).
} 
We talked of building a project called Spaces of Hope in the Neoliberal University, where we would scamper around, full of youthful excitement again, working out what constitutes a space of hope, identifying and documenting those that exist and asking how more might be created. ... Our ultimate aim was to contribute to a new economy of hope, where these precious resources and their strategic utilisation combine so as to achieve a multiplier effect, spreading hope back through the university sector globally. (Kenway et al., 2014, p. 2)

The desire for a 'youthful excitement' in academic work is also evident in the work of Evans and Reid (2014; 2015) who examine possibilities for the academic beyond the standard critique of the neoliberal university and an academic's 'survivability'. They ask "[m] ust we simply accept our vulnerable and precarious status as producers, such that education, like anything else, is prone to catastrophic failure?" and "what does it mean to deny us the possibility of constructing new imaginaries and concepts for political belonging beyond the catastrophic imaginaries of late liberal rule?" (Evans \& Reid, 2014, p. xii). What Evans and Reid are exploring through these questions is the possibility of a different vision of academic becoming, one not dictated by the changing market priorities of the sector but "out of love for the impossible, the intangible, and for the poetry of imagining and crafting lives that may be lived with dignity and freedom" (Evans \& Reid, 2014, p. xii). It is within this hopeful poetry of imagining that we wish to work. Not because we expect a utopian working life to be free from difficulties and integrity to the position of office, but rather that such hopeful poetry is essential to complement the challenges accompanying competitive individualism within the academic precariat. For this particular purpose we draw on our own excavation and analysis of memories of six female academics.

There is an emerging body of literature exploring the ways in which women occupy, contest and negotiate spaces within the academy (see, for example, Lemon \& Garvis, 2014; Budge, 2014; Fitzgerald, 2014; Jackson \& Mazzei, 2012). For example, Budge (2014, p. 77), in her work on early career female academics, argues that despite the institutional challenges, there remain "pockets of agency that enable the possibility of constructing, reconstructing, crafting and shaping academic identity in new and exciting ways." Similarly, Gill (2009, p. 229), in her chapter on the neoliberal university states:

What would we find if, instead of studying others, we focussed our gaze upon our own community, and took as our data not the polished publication or the beautifully crafted talk, but the unending flow of communications and practices in which we are all embedded and enmeshed ... In short, how might we begin to understand the secrets and silences within our own workplaces, and the different ways in which they matter? 
In contributing to this emerging body of literature in this paper, we required a methodology that would enable us to retain such a vision.

\section{Collective biography as methodology}

Once we start talking

Stories spill out

Lap over each other

Wash us into other stories

(Gannon, in Davies \& Gannon, 2006c, p. 117)

Methodologically this paper draws on the work of Davies and Gannon (2006a) and colleagues who developed 'collective biography' as a feminist poststructural research strategy in the social sciences and education, based on the earlier 'collective memory work' of Haug and colleagues (1987). Collective memory work involves a group of researchers talking about and writing down their memories from a particular moment in time and then coming together to share, listen and analyse these stories as a collective to see where there might be overlaps and differences in the take up of particular discursive positions and consequently possibilities for thinking differently. Through this work Haug and colleagues sought to address what they perceived as a gap between Marxist theory and their own experiences as women, disrupting established ways of using theory. Such work is primarily intended to be transformative and therapeutic by developing the researchers' capacities for resistance to oppressive versions of femininity. While drawing on Haug et al. in the writing and analysing of their collective stories, Davies and colleagues (1997) are more concerned with the research potential of collective biography, rather than its therapeutic benefits. Where Haug views Foucault as failing to account for the possibilities of agency in their work, Davies and colleagues find Foucault's ideas useful in treating memories as mo(ve)ments rather than fixed and linear, in order to research the working of “organisms, forces, energies, materials, desires, thoughts, etc" (Foucault, 1980, p. 97). In doing so Davies and colleagues $(1997$, p. 63) draw on a Foucauldian perspective to make visible and revisable the discourses in the texts that construct particular meanings and selves:

Through active listening, and telling, and interrogation of each other's stories, each person comes to imagine new moments of being and perceive the experiences of others as similar to her own moments of being. With each telling the moments themselves and the texts out of which the moments were created become more visible. 
While there are no strict guidelines for how to go about collective memory work or collective biography, broadly speaking the approaches involve firstly choosing a mutually agreed upon theme/research focus (e.g. 'fear') written in 'non-scientific' or vernacular language (e.g. 'a time when I was afraid') as this is seen to elicit richer and more personal accounts from participants. The researchers are then given some time to think about and write down memories of past events related to this theme focusing on the bodily affects. Researchers are encouraged to make explicit the emotions, physical sensations, actions and materials that make up the experience, rather than focusing on an explanation or rationale for what took place. This was a novel methodology to write the self into given the twofold resonance of paying attention to the centrality of our corporeality not only as researchers but also in most cases as educators in PESP. The researchers are also encouraged to write in third-person to help 'distance' themselves from the story and so that they include details that might be taken for granted in a first-person narration. Once written, the authors come together again to share and listen to each other's stories. This then leads to a process of rewriting, with the paper in its entirety being passed from author to author, though not all will necessarily feel comfortable altering other authors' sections.

Key to this process is a loosening of the 'self' in the story - a 'deterritorializing' of the stories-whereby "[t]he authorial 'I' of the story/memory becomes a 'We,' enabling a shared sense of being/becoming" (Gonnick \& Gannon, 2010, p. 66). This is a political act, one that allows people to rewrite their stories in light of other stories, to recognise that their experiences are not irrelevant or a result of some innate deficiency but rather part of a larger process of subjectification that they have a right to question. Consequently, collective biography offered an ideal framework for this paper because it enabled us a way of bringing together and interrogating the diverse narratives and subjectivities of the six authors, removed from a responsibility to tell a whole or single truth about ourselves or our individual experiences. It also allowed us to emphasise the materials, desires and thoughts that might typically be seen as peripheral or irrelevant within contemporary academic life. Working 'collectively' also allows us to challenge the "competitive individualism" ( $\mathrm{Ng}, 2015$, p. 154) present in the neoliberal university while maintaining openness to possibilities for thinking and acting otherwise, or as Davies and Gannon (2011, p. 132-133) explain, "writing as a way of coming to know, and writing as a way of keeping knowing open". This 
explorative approach to sharing our experiences seemed to us key to recognising that "the world is full of stories not just waiting to be told, but also to be written, retold, read and reread" (Tamboukou, 2015, p. 37).

Utilising such a methodology required a number of steps, although the enactment of these steps was far 'messier' than could have been anticipated. While the process of collective biography suits face-to-face workshops and meetings, due to the fact that most of the authors live all over Australia, many with precarious employment and family commitments, the vast majority of discussions took place by email and phone over the course of two years. We began by deciding upon the mutually agreed and vernacular theme of 'life post-Phd', based on our initial discussions over lunch. We wanted to focus on, and potentially in some cases trouble, the notion of being part of the supposed 'academic precariat'. From the outset it was clear from discussions that some of the authors were conscious that they did not want to 'whinge' or focus on the negative implications of the neoliberal turn in academia, while others were more interested in explicit forms of resistance to the neoliberal. Over the next few weeks we each wrote an initial draft based on a memory that was significant to us and entangled with our experience of academia. These stories, each between one and five pages, then formed the data for an analysis. We took the stance that the texts were "partial, incomplete, and always being re-told and re-membered" (Jackson \& Mazzei, 2012, p. 3).

Once everyone had emailed through their initial drafts, the lead author compiled these into one document before distributing among the group so that everyone could read their passages in the context of the others. This led to many reworking or refining their vignettes in various ways, either adding further details or removing sections that no longer felt relevant. The second author then took these passages and distilled them into poems, pulling out key lines, particularly those that evoked a unique sense of time and place, including cited quotes (from friends, family, colleagues, theorists or songs) metaphors, disruptions, diversions, as well as descriptions of self, bodily sensations and emotions. The lead author then titled the vignettes based on a particular image, metaphor or artefact described in the vignette, focusing on the everyday, material and familiar, but also not what might be normally associated with memories of academia. At this stage four of the authors began to write the accompanying analysis, pointing to the connections and different ways of presenting 
the academic subject. This was then emailed to the whole group for another opportunity to rework their vignettes.

Part of the challenge of collective biography is that it can easily lead to very lengthy texts. Typically in journal papers the texts are not presented in their entirety but rather excerpts are woven through the paper (e.g. Zabrodska et al., 2011; Gale \& Wyatt, 2008; Speedy, 2005a, 2005b; St Pierre, 1997). We prevaricated about whether or not to merge the vignettes or to include the vignettes as distinct passages. As we experimented with ways to analyse and present the revised vignettes we departed slightly from a 'traditional' collective biography and drew on the work of Santoro and colleagues (2001) and others (Sparkes \& Templin, 1992; Welch, 2013) that emphasises the 'poetic' as "[a]lternative forms [that] force the reader, suddenly estranged from the norm, to suddenly question the whole production of research as unproblematical reading" (Santoro et al., 2001, p. 194). This approach had the advantage of drawing out the 'moments' within the vignettes that were most relevant to the collective due to their similarities and differences. It also gave us the license to become poetic within our research, an understanding that reflects our attempts to rupture the dominant narrative of academic life and engage with notions of hope.

\section{The poetic vignettes}

The following vignettes are intended to provide and provoke 'different truths' about ourselves as female academic subjects beyond that offered by the neoliberal 'academic precariat'. We offer a new aesthetics of existence through the re-creation of our subjectivities as academic, as female and as ethical.

\section{Vignette 1: brushing teeth}

Finishing the $\mathrm{PhD}$

a perceived act of heroism,

somehow more learned,

lucky to be amongst a privileged few?

A dangerous and strong gravitational pull.

A slow burnout.

At times well deserved reputations of

“impractical waffle,

thinly disguised ideology or

pretentious re-statements 
of common knowledge"

Reciting respected and reputable,

Connell.

Breaking up with academia

It's not you, it's... no, maybe it's you, or me?

A discomfort to a sense of self.

A need for time and space,

for simple language

and a retraction from saying 'yes'.

A new 'coal-face' job on the outside;

new truths and transcendence in abundance

silencing academic work and theory.

Brushing her teeth;

longevity, efficiency and health maximisation

overriding plans for the next morning

and the mornings ahead.

Proverbial 'neoliberal' slithers

of performance enhancement

conflating with apparent changes,

hit home.

Theory again,

imagination and reason.

The lure of uncertainty

and questioning the familiar.

A valued skill from academic becoming, learning to live with paradox.

Seeker Lover Keeper

"I love you more when I'm missing you, that's why I'm always away".

\section{Vignette 2: lifejackets}

Baby number one helps write Honours.

Baby number two helps write $\mathrm{PhD}$.

Good thinking equals having babies?

Landing an 18 month, 3-days/week contract.

Maybe time for her husband's vasectomy. 
"How do you do it,

being an academic and a mum of small kids?"

The assumption that one is not able.

Should not be able.

Better question: how do you $d o$

the full-glory-academic-five-year-dash

on a part-time loading,

casual position or fixed-term contract?

Cue the musical theme from Indiana Jones:

dum du dum dah, dum du dah...

Funny. Phantasmagorical.

There's no such thing as part-time academia.

stay-home parents

remain 'valued casuals'

Flexible hours

working full time in spare time

thinking, writing, more writing, keep writing

It's about the opportunities. It's it's opportunities ...

"It's it's Mabo, it's justice, it's law, it's the vibe"*

Floundering. Fumbling.

Negotiating this seeming impossibility

makes parenting

a life-jacket for keeping afloat.

Kids. Keeping it real. Keeping life lovely.

Repudiating discontent

about being 'stuck' in the academic precariat.

Precarity at work, priority at home.

It's perfect. Perhaps.

At least, for now.

* Popularised quote from the Australian movie, The Castle (1997)

\section{Vignette 3: rulebook ruptures}

$\mathrm{PhD}$ finished

and tenure gained;

opportunities abundant.

Then the illness and death of her husband. 
On one side of that moment he was present,

on the other he was not.

She remembers saying "he's gone", to no one in particular.

She wasn't sad, she wasn't really anything.

She sat holding his hand, still for hours.

It was peaceful, for a speck of time.

Looking for 'meaning'.

The joy and love of research with young people 'doing it tough'.

Working in remote Indigenous communities.

On country. In country.

Back home.

A newfound ruthlessness determining

with whom, and on what, time is spent,

sitting comfortably alongside

the tenuousness of life.

People - making, sustaining, transcending;

arising from a sense of loss.

Throwing aside the 'rulebook'

of structure, process, policy.

The impersonal fades,

part of the ebbs and flows of such ruptures.

A challenge for change

for this disruption, alongside these people.

Establishing new ways to be.

\section{Vignette 4: lolly counters and dusty halls}

2014: the death of Prime Minister Gough Whitlam.

A legacy of 'chance and opportunity'

PhD awarded.

How did this happen?

Remembering:

A fourth grade teacher to a class of scrubby country kids,

"only four more years until you can leave school".

Her mother taking her to the Coles lolly counter,

whispered in her ear,

"maybe one day you'll get to work here". 
Education as functional;

her place in society set.

High school

Ready to leave

until a talent found and loved.

Her music teacher handed her a flute:

"you can thank Mr Whitlam for this".

Fighting to stay.

Year 10.

Then Year 12.

Aunts and uncles: "what if she fails?", "she's a bludger".

Mum: "then I'll be here".

'First in family' to graduate Year 12

meant finding new ways to think and be

but determined not to be 'flash' or 'up herself'

fitting into both worlds.

University.

Gough opened up the dusty halls of university

to people like her.

But still a working class, country girl

Enjoying the rigour and collegiality

of the PhD.

Discussions confronting and challenging,

supportive and exciting.

Now a doctor

and in the forward of her PhD she wrote:

"Thanks, Gough".

\section{Vignette 5: mud and play dough}

A permanent academic position.

She recognises the privileges that brings.

Yet the lived-ness and daily-ness

of academic-hood and mother-hood

seem muddy and slippery.

A clash between 
'good mum' and 'good academic'.

A good mum is $100 \%$ committed to her children.

A good academic publishes countless papers,

establishes a strong track record and an 'international profile'.

Some days she just wants to play with play dough in her pyjamas.

Three long maternity leaves,

returning part-time,

providing some sort of balance/survival.

Eleven years!

No promotion,

or large, competitively funded research grant.

Like the tortoise,

though hard not to see these choices as failings.

A friend interprets these choices as a refusal.

A political stance - an active stance,

a shift in the terms of the game

to insist on living academic-hood differently.

\section{Vignette 6: memes, manifestos and Michael Jordan}

\section{Artefact 1}

A black and white photograph of Michel Foucault;

smooth bald head,

easy to Photoshop,

stuck haphazardly on the office door

alongside Zizek, Bourdieu, Butler.

Their door of celebrity theorist memes;

a playful affront

to the quantitative child obesity researchers

across the corridor.

Artefact 2

A pocket-sized collection of photographs.

Photos of objects from around the room;

the messy desk,

the retro heater,

herself 'in situ', head in hands, staring blankly at the screen.

A memento for a departing officemate and friend. 
Artefact 3

The thesis acknowledgements page.

Solidifying relationships in black and white,

A grey area between the personal and professional.

Her supervisor, "the Michael Jordan to her Under 12s basketball team",

Her father's pragmatism, "boom, tick, done".

All there. On record.

Artefact 4

The Wright Harwood Finishing School for Ladies (WHFSL).

A joke over dinner solidified through email.

A logo,

a general meeting,

a manifesto for the fridge.

We could have some fun with this.

\section{Other ways of being: understanding the vignettes}

Collectively these vignettes reflect the blurred line between the personal and the professional, the theoretical and the practical. Within the recounted mo(v)ements of joy, frustration, tragedy and triumph, layers of familial relations, academic identity, entrepreneurialism, gender and geographical location are negotiated, ruptured and formulated. These vignettes privilege the emotions, relationships and material artefacts used to both connect and divert. These are a work in progress as we seek to reclaim a new space to think otherwise about our academic lives. These vignettes recognise the humour, tragedy and the importance of relationships both within the academy and within our personal lives, as well as the beauty, meaning and appreciation we have for the academic work we do. Vignette 1 explores the paradox of appreciating the academy more when no longer directly involved in it. Vignette 3 explores efforts to find meaning and reignite belief in the importance of people and relationships in work following personal loss. Vignette 2 and 5 explore motherhood and its differing a/effects on, and relationship to, academic work. Vignette 4 explores the role of class and history on academic expectations and experiences. Vignette 6 draws on four material artefacts to highlight the importance of friendship, deviations and humour in the necessary and everyday joys of academic work.

Through the collective development of these vignettes we have sought to establish a new aesthetics as female, as academic and as ethical subjects. As 'female', these 
vignettes claim a space that says that those aspects of femininity that may be typically positioned outside the professional space of academia (e.g. the personal, the emotional, the humorous and the relational) should be recognised as vital to and revitalising of academic subjects. As an all female sample, this is a unique documentation of solidarity within and without PESP given the 'stable gendered patterns' that mark the field; where particular transmissions of what counts as 'gender legitimate' knowledge dispositions are enculturated in the profession (Brown \& Rich, 2002, p.80). As 'academic', these vignettes position academic work in terms of its beauty, meaning, warmth, creativeness and liveliness; taking precedence over the processes, structures and economics that support such work. As 'ethical', these vignettes present the prioritising of what, and who, has meaning and worth beyond what is necessarily productive or strategic. These seem to be choices related to our ethics concerning the primacy of people; we place family and the work of motherhood above the work of an institution and see relationships as valuable and deserving of nurture.

The 'academic' and 'ethical' challenges are however in constant movement, which this very process of writing a collective biography has helped us to know. The vignettes recognise the momentary nature of experience; the now-ness of these moments that may well be very different to the now-ness of future moments. We are therefore aware of using writing as a way of 'keeping knowing open' and wonder what movements and materialisations of memory will emerge in our future academic work (Davies \& Gannon, 2011).

What this collection of vignettes does is challenge the understanding of how things are meant to be, giving possible alternative understandings of our acts of agency to sit alongside the acts of others. As Evans and Reid (2014, p. xii) state:

Confidence and principles about reclaiming the meaning of the University as such go out of the window as we are told to accept the intellectual realities of the times. The friendships we openly celebrate with colleagues and students alike categorically reject this model which, at best, continues to lead to the promotion of intellectual mediocrity, while at worst, naturalizing new forms of insecurities by disingenuous careerists who militaristically continue to rank and profile colleagues.

Such offerings contribute to a wider project that suggests a return to what Evans and Reid (2015, p. 5) call "the original philosophical rupture - the poetic" which enables us to consider "a new imaginary for rethinking politics, emancipation and the formation of political communities in the twenty-first century". According to Evans 
and Reid (2015, p. 5), such a poetic subject "demands a more confident political register that openly welcomes a more crafted art for living dangerously." From each of our vignettes, common threads appeared despite the separateness of the writing involved and the experiences at the heart of these writings. Each of us expressed and acted in 'hope', that was strongly attached to a will for change. Such hopeful practices are rooted in what Braidotti (2013, p. 24) describes as the "ordinary micro-practices of everyday life" and a way of "dreaming up possible futures: an anticipatory virtue that permeates our lives and activates them".

\section{Shaking things up: choices and conclusions}

This paper has questioned what it means to be an academic in the precarious modern university. We, like Grosz (1995, p. 126-127), believe that texts such as these have "short term effects" and only remain effective if they "produce realignments, shake things up". The purpose was not to necessarily reduce, resist or go beyond this precariousness, but rather to shake up the disembodied label that is the 'academic precariat'. This is in part the result of sharing our experiences with each other as we navigate our lives in and outside the academy in 'precarious times'. It was also possible because, to put it simply, we like each other; we want to work with each other, support each other, not because it will help us 'get ahead' but because we care about each other and get joy from engaging with each other and other people in our lives, creating things together, working in spaces where we feel comfortable putting forward the playful, the poetic and the 'half-baked'. This is who we are and what we gain from each other as a collective. Such an admission may be perceived as a form of indulgent navel-gazing. Yet these caring and playful encounters help us to keep knowledge 'alive' that we aspire, as a collective, to contribute to the development of a different political imagination; one that propels our work and offers research insights into both teacher education and PESP pedagogy and scholarship. In writing this paper we sought to challenge popular notions of what it means to be an academic, offering a space for 'thinking otherwise' (Barcan, 2013) about ourselves as academic subjects by focusing on emotive, corporeal and bodily mo(ve)ments central to our lives and work that are not so evident within the literature or even PESP corporeal discourses. We participate with the hope that the friendships, the humour, our promises to ourselves and others, are an ongoing part of our everyday academic lives and a mechanism of 'groundedness' that resists us being reduced to disembodied neoliberal 
subjects beholden to the economics of the university. Paradoxically, this groundedness was made possible thanks to our links beyond the physical confines of the institution. This speaks to the non-linear ways in which women in particular have had to negotiate professional and private lives. What began as an informal conversation over lunch between good friends has turned into a much deeper reflexive engagement that we hope adds complexity to the literature, or 'shakes things up', regarding life in the neoliberal university and beyond.

\section{Acknowledgements}

The authors wish to thank the two anonymous reviewers of this paper for their insightful, generous and encouraging feedback. Such scholarship is a prime example of the sort of collegiality and intellectual curiosity that we hope to foster in our professional lives and relationships. The authors also wish to thank Jan Wright for her invaluable feedback on an earlier iteration of this paper and her ongoing mentoring as the backbone of the WHFSL.

\section{List of references}

Ahmed, S. (1998). Differences that matter: Feminist theory and postmodernism. Cambridge, UK: Cambridge University.

Barcan, R. (2013). Academic life and labour in the new university: Hope and other choices. Surrey, UK: Ashgate.

Barcan, R. (1996). The body of the (humanities) academic, or, "what is an academic?'. Southern Review: Communication, Politics \& Culture, 29(2), 128-145.

Braidotti, R. (2013). Becoming-world. In R. Braidotti, P. Hanafin, \& C. Blaagaard (Eds.), After cosmopolitanism (pp. 8-27). New York: Routledge.

Brown, D., \& Rich, E. (2002). Gender positioning as pedagogical practice in teaching physical education. In D. Penney (Ed.), Gender and physical education: Contemporary issues and future directions (pp. 80-100). London: Routledge.

Casey, A. \& Fletcher, T. (2012). Trading places: From physical education teachers to teacher educators. Journal of Teaching in Physical Education, 31(4), 362-380.

Clarke, M. (2004). Reconceptualising mentoring: Reflections by an early career researcher. Issues in Educational Research, 14(2), 121-143.

Connell, R. (2013). The neoliberal cascade and education: An essay on the market agenda and its consequences. Critical Studies in Education, 54(2), 99-112.

Davies, B., \& Gannon, S. (2011). Collective biography as pedagogical practice: Being and becoming in relation to place. In M. Somerville, B. Davies, K. Power, S. Gannon, \& P. de Carteret (Eds.) Place pedagogy change (pp. 129-142). Rotterdam: Sense. 
Davies, B., \& Gannon, S. (Eds.) (2006a). Doing collective biography: Investigating the production of subjectivity. Berkshire, UK: Open University.

Davies, B., \& Gannon, S. (2006b). The practices of collective biography. In B. Davies, \& S. Gannon (Eds.) Doing collective biography: Investigating the production of subjectivity (pp. 1-15). Berkshire, UK: Open University.

Davies, B., \& Gannon, S. (2006c). A conversation about the struggles of collaborative writing. In B. Davies, \& S. Gannon (Eds.) Doing collective biography: Investigating the production of subjectivity (pp. 114-144). Berkshire, UK: Open University.

Davies, B., Dormer, S., Honan, E., McAllister, N., O’Reilly, R., Rocco, S., \& Walker, A. (1997). Ruptures in the skin of silence: A collective biography. Hecate, 23(1), 6279.

Davies, B., \& Bansel, P. (2007). Neoliberalism and education. International Journal of Qualitative Studies in Education, 20(3), 247-259.

Davies, B., \& Bansel, P. (2005). The time of their lives? Academic workers in neoliberal time(s). Health Sociology Review, 14(1), 47-58.

Deleuze, G. \& Guattari, F. (1988). A thousand plateaus. London: Athlone.

Evans, B., \& Reid, J. (2015). Exhausted by resilience: Response to the commentaries. Resilience: International Policies, Practices and Discourses, 3(2), 154-159. DOI: 10.1080/21693293.2015.1022991

Evans, B., \& Reid, J. (2014). Resilient life: The art of living dangerously. Cambridge: Policy.

Fischer, C. (2013). Moral musings on philosophy, gender, and the academic precariat. APA Newsletter on Feminism and Philosophy, 12(2), 15-17.

Fitzgerald, T. (2014). Women leaders in higher education: Shattering the myths. London: Routledge.

Foucault, M. (1980). Two lectures. In C. Gordon (Ed.), Power/knowledge: Selected interviews and other writings 1972-77 by Michel Foucault (pp 78-108) (C. Gordon, L. Marshall, J. Mepham \& K. Soper, Trans.). Brighton: Harvester.

Gale, K. \& Wyatt, J. (2008). Becoming men, becoming-men?: A collective biography. International Review of Qualitative Research, 1(2), 235-253.

Gilbert, P. (1992). The story so far: Gender, literacy, and social regulation. Gender and Education, 4(3), 185-199.

Gill, R. (2009). Breaking the silence: the hidden injuries of the neoliberal university. In R. Flood \& R. Gill (Eds.), Secrecy and silence in the research process: Feminist reflections (pp. 228-244). London: Routledge.

Giroux, H. (2014). Public intellectuals against the neoliberal university. In N. K. Denzin \& M. D. Giardina (Eds.), Qualitative inquiry outside the academy (pp. 35-60). Walnut Creek, CA: Left Coast.

Giroux, H. (2011). Neoliberalism and the death of the social state: Remembering Walter Benjamin's Angel of History. Social Identities, 17(4), 587-601.

Gonick, M. \& Gannon, S. (2014). Becoming girl: Collective biography and the production of girlhood. Toronto: Women's Press. 
Gonick, M. (2014). Producing neoliberal subjectivities: literacy, girlhood, and collective biography. Cultural Studies $<=>$ Critical Methodologies, 15(1), 64-71.

Grosz, E. (1995). Space, time and perversion. New York: Routledge.

Haug, F., Andersen, S., Bunz-Efferding, A., Hauser, K., Lang, U., Laudan, M., Ludemann, M., Meir, U., Nemitz, B., Niehoff, E., Prinz, R., Rathzel, N., Scheu, M., \& Thomas, C. (Eds.) (1987). Female sexualisation: A collective work of memory (E. Carter, Trans.). London: Verso.

Hilgers, M. (2013). Embodying neoliberalism: Thoughts and responses to critics. Social Anthropology, 21(1), 75-89.

Jackson, A. \& Mazzei, L. (2012). Thinking with theory in qualitative research: Viewing data across multiple perspectives. London: Routledge.

Jessop, B. (2013). Embodying neoliberalism: thoughts and responses to critics. Social Anthropology, 21(1), 65-74.

Kenway, J., Boden, R. \& Fahey, J. (2014). Seeking the necessary 'resources of hope' in the neoliberal university. In M. Thornton (Ed.), Through a glass darkly: The social sciences look at the neoliberal university. Canberra, ACT: ANU.

Khoo, T. (2014). Right back where we started from. In N. Lemon \& S. Garvis (Eds.), Being "in and out": Providing voice to early career women in academia (pp 57-67). Rotterdam: Sense.

Lemon, N. \& Garvis, S. (Eds.) (2014). Being “in and out”: Providing voice to early career women in academia. Rotterdam: Sense.

Macfarlane, B. (2011). The morphing of academic practice: unbundling and the rise of the para-academic. Higher Education Quarterly, 65(1), 59-73.

May, R., Strachan, G., Broadbent, K. \& Peetz, D. (2011). The casual approach to university teaching: Time for a re-think?. In K. Krause, M. Buckridge, C. Grimmer, \& S. Purbrick-Illek, (Eds.), Research and development in higher education: Reshaping higher education, 34 (pp. 188 - 197). Gold Coast, Australia, 4 - 7 July 2011.

$\mathrm{Ng}$, E. (2015). Questioning the role of 'faith' in a micropolitics of the neoliberal university. SITES, 12(1), 153-177.

Nöbauer, H. (2012). Affective landscapes in academia: emotional labour, vulnerability, and uncertainty in late-modern academic work. International Journal of Work Organisation and Emotion, 5(2), 132-144.

Olssen, M. \& Peters, M. (2005). Neoliberalism, higher education and the knowledge economy: from the free market to knowledge capitalism. Journal of Education Policy, 20(3), 313-345.

Peters, M., Marshall, J., \& Fitzsimons, P. (2000). Managerialism and education policy in a global context: Foucault, neoliberalism and the doctrine of self-management. In N. C. Burbules \& C. A. Torres (Eds.), Globalization and education: Critical perspectives (pp. 109-132). New York, NY: Routledge.

Petersen, E. B. (2011). Staying or going? Australian early career researchers' narratives of academic work, exit options and coping strategies. Australian Universities Review, 53(2), 34-42.

Rizvi, F. \& Lingard, B. (2010). Globalizing education policy. Oxford: Routledge. 
Rowlands, J. \& Rawolle, S. (2013). Neoliberalism is not a theory of everything: A Bourdieuian analysis of illusion in educational research. Critical Studies in Education, 54(3), 260-272.

Somerville, M. (2005). Postmodern emergent methodologies, paper presented to the First International Congress of Qualitative Inquiry, Urbana-Champaign, 5-7 May.

Speedy, J. (2005a). (with Margie, Fay, Jack, Pauline \& Janice Jones). Failing to come to terms with things: A multi-storied conversation about poststructuralist ideas and narrative practices in response to some of life's failures. Counselling and Psychotherapy Research, 5(1), 65-73.

Speedy, J. (2005b). Collective biography practices: Collective writing with the unassuming geeks group, British Journal of Psychotherapy Integration, 2(2), 29-38.

St Pierre, E. (1997). Circling the text: Nomadic writing practices. Qualitative Inquiry, 3(4), 403-417.

Standing, G. (2011). The precariat: The new dangerous class. London: Bloomsbury Academic.

Stubb, J., Pyhältö, K., \& Lonka, K. (2011). Balancing between inspiration and exhaustion: PhD students' experienced socio-psychological well-being. Studies in Continuing Education, 33(1), 33-50.

Tamboukou, M. (2015). Narrative phenomena: entanglements and intra-actions in narrative research. In M. Livholts \& M. Tamboukou (Eds.), Discourse and narrative methods: Theoretical departures, analytical strategies and situated writing (pp. 3747). Los Angeles: Sage.

Withers, D. \& Wardrop, A. (2014). Reclaiming what has been devastated. In A. Wardrop \& D. Withers (Eds.), The para-academic handbook: a toolkit for makinglearning-creating-acting (pp. 6-12). Bristol: HammerOn.

Zabrodska, K., Linnell, S., Laws, C., \& Davies, B. (2011). Bullying as intra-active process in neoliberal universities. Qualitative Inquiry, 17(80), 709-19.

Ziarek, E. P. (2001). Rethinking dispossession: On being in one's skin. Parallex, 7(2), 3-19. 